\title{
Shopping Habits, Brand Loyalty and Brand Preference: Exploring Consumers' Behaviour during a Recession
}

\author{
Kelisha Govender \\ Research Graduate: School of Management, IT and Governance \\ University of KwaZulu-Natal, South Africa \\ Krishna Govender \\ Dean: Regenesys Business School \\ Honorary Research Associate: University of KwaZulu-Natal, South Africa \\ E-mail: krishnag@ regenesys.co.za
}

Received: August 1, 2013 Accepted: September 5, 2013 Published: December 5, 2013

doi:10.5296/bms.v4i2.4674 URL: http://dx.doi.org/10.5296/bms.v4i2.4674

\begin{abstract}
This paper reports the findings of an exploratory study conducted among a sample of 313 customers at a major mall in Pietermaritzburg, KwaZulu-Natal, South Africa to determine consumers' perceptions of private label brands versus manufacturer brands during an economic recession and, to ascertain whether higher Living Standard Measure (LSM) groups are loyal to established manufacturer brands or if they switch to private label brands during an economic recession. Relationships were postulated among several variables by developing nine hypotheses and, evaluating these using Chi-square and Spearman's correlation. The findings may be useful to retailers in that they could respond to the increasing power of brands during an economic recession, and not only improve their branding strategies in order to ensure their 'survival' during a recession, but also become aware of how consumers perceive private brands and how this perception can be improved to promote brand loyalty. Manufacturers may also become aware of strategies to adopt during a recession to ensure brand loyalty and minimize brand switching.
\end{abstract}

Keywords: Shopping habits, Consumer behavior, Brand loyalty, Brand switching, Brand preference 


\section{Introduction}

An economic recession may be defined as an economic situation in which a country's gross domestic product or output is sustaining a negative growth (Hata, 2008:1). According to the National Bureau of Economic Research, a recession is a significant decline in economic activity which lasts for a period between eleven months and two years (Feldstein, 2003:1). The recession experienced in recent years has obliged South African consumers to adapt and change their consumption behaviour in order to cope financially. Most often, the effects of a recession on consumer shopping behaviour results in consumers becoming cautious and such buying habits tend to remain for while even after the recession (Simpson 2009). Thus, the scope of consumer survival strategies resulting from these adaptations is important to incorporate in future marketing strategies in order to satisfy consumer demands.

By evaluating the pre-recessionary and post-recessionary consumer, the marketer of manufacturer of retailer brands will be able to understand what drives a brand's current and future equity and, the existence of brand loyalty and its contribution to any return on investment, such as market share. Most importantly, both the manufacturer and retailer brands need to be differentiated and positioned in order to increase their return on investment and communicate their added values to the consumer, thus allowing consumers to make a choice between competing brands based on the communication strategy of the particular brand (Murphy, 1987:3). Furthermore, it is therefore important for both retailers and manufacturers to understand the shopping behaviour of consumers during a recession, in order to retain consumer loyalty during the recovery (post-recession) period. Thus, the study of brand choice during a recession is significant and relevant to both manufacturers and retailers in order to understand their customers and maintain brand loyalty.

In light of the aforementioned, this paper reports the findings from an exploratory study conducted among a convenience sample of consumers/shoppers in Pietermaritzburg, the capital city of KwaZulu-Natal Province, in South Africa. The primary research question was: Do consumers continue to purchase their familiar manufacturer branded items or do they opt for private label brands during a recession? The aforementioned spawned two key research objectives, namely:

- To determine consumers' perceptions of private label brands versus manufacturer brands during an economic recession; and

- To ascertain whether higher Living Standard Measure (LSM) groups are loyal to manufacturers' brands or if they switch to private label brands during an economic recession.

\section{Manufacturer Brands versus Private Label Brands}

The main function of a brand is to distinguish the goods of one producer from another, thus allowing the consumer freedom of choice (Murphy, 1987:1). Brands serve as a symbolic device, signaling quality, reducing risk and search costs and developing a bond between the 
consumer and the seller. Essentially, a brand that is valued characterises both trust and goodwill (Keller, 2008:7). Generally, there are two types of product brands, namely manufacturer brands and private or retailer/dealer/distributor brands. Manufacturer brands, also known as national brands, can be identified as goods that are created and owned by a producer or dealer (Kotler and Keller, 2006: 126). Manufacturer brands are controlled and produced by manufacturers and sold through a plethora of retailers. Murphy and Leahy (1987:120) state that manufacturers have relied successfully on building their brand names through extensive distribution by retailers, thus building on customer loyalty. Branded products are expected to incorporate the potential level of the brand model to show evidence of greater quality compared to private label goods, and premium brands should display even greater levels of superiority.

Private label brands, also known as retailer brands, refer to those brands created and owned by a specific chain of stores (Murphy, 1987:7). Generally, a distributor is a retailer that either includes a product range with only private labels or, most often, a blend of manufacturer brands and private label brands. The four characteristics of private label brands include low quality generics, medium quality private labels, fairly less expensive but comparable quality products and premium quality private labels. These brands are generally priced less than manufacturer brands. According to Leahy (1987:120), retailers realised that branding ensured that consumers' developed loyalty for goods as a result of value for the brand, regardless of the outlet or competition. Leahy (1987:138-140) identified six benefits of private label brands to assist the retailer, and these include market planning, control, innovation, choice, loyalty, and cost.

Kumar and Steenkamp (2007:2) confirmed that manufacturer brands exploited their power over retailers by becoming 'branded bulldozers' thus dwarfing retailer brands with their extensive price and promotion policies (Beneke, 2010:203). The actual branding challenge however is the difference between price and quality of brands in the market and concerns over consumer expenditure, especially during an economic recession (Kotler and Keller, 2006:132).

Private label brands most often adopted a 'me-too' strategy (copycat brands) which often depicted a brand based on the core benefit or generic level of augmentation. Manufacturer brands in contrast were based on an expected, augmented or potential level thus providing a competitive advantage over private label brands. However in the recent years, private label brands have been evolving to provide consumers with a range of "various priced sub-brands encompassing value, organic, healthy, vegetarian, premium, child-friendly and allergenic products" which shows the increase in the level of augmentation of these brands.

The recession of the early nineties resulted in a close relation partnership between manufacturers and retailers working to develop products that out-price and out-perform other leading brands (Bass and Binder, 2005). Powerful brands are those brands that are well adapted to the environment and thus survive and flourish even during times of an economic downturn, since a recession can sift out weaker brands of lower quality and therefore make 
category leaders even stronger. At the same time, value-based brands can increase brand strength because they present the consumer with a familiar name at a reasonable price (Silverstein 2008).

\section{Consumer Behaviour and Brand Choice during a Recession}

In June 2009, TNS Research Surveys conducted a study amongst a sample of 2000 adults from seven major metropolitan areas of South Africa (Neil, 2009: 1-9) and, the results revealed that the key decisions shoppers make if they are affected by the recession include, postponing making large purchases, buying smaller packages and/or, looking for cheaper brands. Another study conducted among consumers to determine their recessionary shopping behaviour was that by the Home Testers Club, an online survey blog, which allows consumers to comment on products as well as share experiences of good and bad brands (no author, 2010). The following findings pertinent to this research were extracted from the aforementioned study:

- $90.1 \%$ of consumers agreed that they change their shopping habits to make ends meet, and $88.44 \%$ of these agreed to 'hold' these "thrifty, new" recessionary shopping habits,

- $\quad 80.57 \%$ indicated that they bought cheaper lines and, $61.70 \%$ will stick to these lines even after the recession,

- $82.71 \%$ of the respondents decreased the amount of their impulse spending,

- $74.01 \%$ of consumers indicated that they are concerned about value for money,

- $26.55 \%$ revealed that they trusted brands recommended by friends,

- $22.11 \%$ trusted brands recommended in TV adverts,

- $\quad 18.50 \%$ trusted brands recommended by reviews and write-ups, and

- $14.71 \%$ trusted in-store promotions.

A study carried out by AC Nielsen showed that two thirds of global consumers in the developed markets of Europe, the Pacific and North America, considered private label brands to be a "good alternative to other brands" (AC Nielsen 2005). According to the Nielsen Global Private Label Report (2011) shoppers within developed markets will retain their 'value-mindset' even after a recovery of the great economic downturn. These consumers prefer to purchase at stores that offer 'everyday low prices' and will tend to be atypically thrifty. According to the AC Nielsen Report (2005), in comparison to developed markets, consumers in developing markets such as South Africa, are less aware of private label brands and assume from the packaging and price that the brand is of inferior quality and specifically aimed for people that cannot afford to purchase better quality manufacturer brands.

From the AC Nielsen (2011) South African online consumer opinion survey on supermarkets' brands, it became evident that $72 \%$ of the respondents agreed that supermarkets' own brands are a good alternative to other brands; $68 \%$ agreed that supermarket brands are usually 
extremely good value for money, and $47 \%$ of respondents didn't think that supermarket brands are suitable for products where quality really matters. Furthermore, only $28 \%$ agreed that supermarket brands are really meant for people who are on tight budgets and can't afford the best brands.

Despite the global recession in 2009, retail sales in South Africa increased by 5\% to reach $\$ 72$ billion of which food and beverage sales comprised $\$ 7$ billion (The South African Food Sector Report 2009). However, in South Africa, regardless of the growth of retail sales in key supermarket chains such as Shoprite, Pick n' Pay, Spar and Woolworths, private label brands have not achieved a triumphant penetration relative to other countries globally. For example, private label brands contribute $40 \%$ plus to the retail market in developed countries such as Switzerland and the UK while there is only $10.5 \%$ of contribution to the retail market in South Africa (Durham, 2011:35). According to Beneke (2010: 205) a major concern in the South African retail market is the perception of consumers regarding private labels. Beneke (2010) argues that even though it is considered normal for lower income groups to purchase private label brands for affordability reasons, issues such as trust and the availability of private labels result in consumers with limited financial resources purchasing manufacturer brands to avoid any perceived risk. Alternatively, higher Living Standards Measures (LSM 6-10) are wealthier and therefore are open to trial of private labels (Mawers 2006, cited by Beneke, 2010: 205).

According to the AC Nielsen Report (2010), the growth of private label brands and the strength of the economy share an inverse relationship. The economic recession accounted for many consumers purchasing an increased amount of private label brands and once they did try out these brands, they realised that the quality of the brands did exceed their expectations (AC Nielsen, 2010: para12). Lamey et al. (2007, cited by Beneke, 2009:208) confirmed that the adoption rate of private labels is much faster during the economic recession when compared to post recessionary adoption. Durham (2011: 35) supports this notion by declaring that there is no doubt that South African consumers have been encouraged to try private labels during 'trading down' buyer behavior within the recession period but other attributes such as packaging, quality and value for money has also accounted for the loyalty towards in store private labels. Durham (2011) further provides evidence on the private label brands with the highest share in South Africa in ascending order, namely; chicken, sugar, frozen vegetables, dog and cat food, canned pilchards/mackerel, chilled processed meats, margarine, biscuits and ready to eat items.

Complete loyalty to a brand is very rare and often amounted to a minimal percentage of irregular brand and category buyers (Hale, 2009:7). According to Quelch (cited by Das, 2009), in order to recover market share and any return on investment at lower costs during the post-recession period, stores must carry out excessive advertising when their competitors are cutting back during the recession. Consumers tend to re-examine their buying patterns and brand loyalty during the recession where baby boomers who have been faced with tough economic circumstances in the past are now adapting their retirement phase of life to the 
current economic decline.

A research project called "The Solution Workshop" had recently examined how South African consumers have survived during the recession. According to this report, the recession experienced in recent years has made South African consumers adapt and change their behaviour in order to cope financially during the recession. It was also evident that consumers were "tightening their belts" and controlling purchases by planning and budgeting, cutting back on any impulse spending and focusing on discounts, promotions and specials. The scope of consumer survival strategies resulting from these adaptations is important to incorporate in future strategies in order to satisfy consumer demands (SA Trader, 2010: para 15). In view of the above, it is significant for both retailers and manufacturers to understand the cautious mind sets of consumers, to address consumer needs during the recession and to retain consumer loyalty during the recovery period.

In an attempt to shed light on consumer brand choice during a recession, flowing from the brief literature review, nine hypotheses (Table 1) were postulated and examined by conducting an exploratory study among a sample of shoppers at a large shopping mall in South Africa.

Table 1. Hypothesised Relationships

\begin{tabular}{|l|l|}
\hline No. & Hypotheses \\
\hline 1 & $\begin{array}{l}\mathrm{H}_{0}: \text { there is no relationship between the consumers' shopping habits and their } \\
\text { brand preference during a recession } \\
\mathrm{H}_{1}: \text { there is a relationship between the consumers' shopping habits and their } \\
\text { brand preference during a recession }\end{array}$ \\
\hline 2 & $\begin{array}{l}\mathrm{H}_{0}: \text { there is no relationship between the consumers' recession status and their } \\
\text { brand choice } \\
\mathrm{H}_{1}: \text { there is a relationship between the consumers' recession status and their } \\
\text { brand choice }\end{array}$ \\
\hline 3 & $\begin{array}{l}\mathrm{H}_{0}: \text { there is no relationship between the consumers' shopping habits during a } \\
\text { recession to suit their budget and, their brand preference } \\
\mathrm{H}_{1}: \text { there is a relationship between the consumers' shopping habits during a } \\
\text { recession to suit their budget and, their brand preference }\end{array}$ \\
\hline 4 & $\begin{array}{l}\mathrm{H}_{0}: \text { there is no relationship between the consumers' shopping habits during a } \\
\text { recession to suit their budget and, their inclination to buy Private label brands } \\
\mathrm{H}_{1}: \text { there is a relationship between the consumers' shopping habits during a } \\
\text { recession to suit their budget and, their inclination to buy Private label brands }\end{array}$ \\
\hline $\begin{array}{l}\mathrm{H}_{0}: \text { there is no relationship between the respondents' brand loyalty and their } \\
\text { preference for Manufacturer brands, irrespective of their financial status } \\
\text { during a recession } \\
\mathrm{H}_{1}: \text { there is a relationship between the respondents' brand loyalty and their } \\
\text { preference for Manufacturer brands, irrespective of their financial status }\end{array}$ \\
\hline 5 &
\end{tabular}




\begin{tabular}{|l|l|}
\hline \multicolumn{1}{|l}{} & during a recession \\
\hline 6 & $\begin{array}{l}\mathrm{H}_{0}: \text { there is no relationship between the consumers' brand loyalty during a } \\
\text { recession and their recession status } \\
\mathrm{H}_{1}: \text { there is a relationship between the consumers' brand loyalty during a } \\
\text { recession and their recession status }\end{array}$ \\
\hline 7 & $\begin{array}{l}\mathrm{H}_{0}: \text { there is no relationship between the consumers' brand loyalty and their } \\
\text { brand awareness during a recession } \\
\mathrm{H}_{1}: \text { there is a relationship between the consumers' brand loyalty and their } \\
\text { brand awareness during a recession }\end{array}$ \\
\hline 8 & $\begin{array}{l}\mathrm{H}_{0}: \text { there is no relationship between the consumers' brand loyalty and their } \\
\text { preference for manufacturer brands during a recession } \\
\mathrm{H}_{1}: \text { there is a relationship between the consumers' brand loyalty and their } \\
\text { preference for manufacturer brands during a recession }\end{array}$ \\
\hline 9 & $\begin{array}{l}\mathrm{H}_{0}: \text { there is no relationship between the higher Living Standard Measure } \\
(\text { LSM) groups who are loyal to established manufacturer brands and their } \\
\text { potential to switch to private label brands during an economic recession. } \\
\mathrm{H}_{1}: \text { there is a relationship between the higher Living Standard Measure (LSM) } \\
\text { groups loyal to established manufacturer brands and their potential to switch } \\
\text { to private label brands during an economic recession. }\end{array}$ \\
\hline
\end{tabular}

\section{Research Methodology}

Since descriptive research explains market conditions such as the prospects of a brand, attitudes and demographics more comprehensively (Kotler and Armstrong, 1996:118), this study is descriptive and assists in understanding and describing the nature of the population with respect to the research questions, more especially associations among various variables that affect the consumers' shopping habits during an economic recession (Cooper and Schindler, 2007:202).

A questionnaire was used to collect data from a random convenient sample of shoppers who were shopping at a large mall, by way of the mall intercept survey method. The mall intercept survey method involves collection of data in which a sample of respondents passing through a shopping mall are stopped (intercepted) and asked to participate in a research study (Brown, Churchill and Tracy, 2009:202). The mall intercept survey was chosen as it permits the researcher to reach respondents in a location where they naturally gather together as consumers in a shopping environment and, also benefits the researcher in terms of convenient low cost data collection and quick collection due to time constraints and sample control.

\subsection{The Research Instrument}

A semi-structured questionnaire which allows for structured and unstructured questions was used where, in addition to 'pre-defined answers', respondents were also given the opportunity to provide explanations (Hague, 1993:21), so as to avoid respondents being forced into a decision, given the pre-defined answers. The mostly Likert-scale type questions posed to 
respondents were classified into Behavioural and Attitudinal, with Behavioural questions obtaining data regarding the respondents' frequency of choice and their shopping habits, and Attitudinal questions, obtaining data regarding the respondents' image of and ratings of brands and explanation of their brand preferences. Respondents had to rate how strongly they agreed or disagreed with carefully constructed statements portraying their positive or negative attitudes toward the matter (Brown, Churchill and Tracy, 2009:270). In addition, classification questions assisted in obtaining data regarding the respondent's demographics, more specifically data which was able to permit the researcher to group respondents to make valid comparisons (Hague, 1993:30).

\subsection{Sample and Sampling}

Since the two main objectives of the study were to determine whether consumers purchased manufacturer brands or private label brands and, their perceptions of these two brands during the economic recession, it was most appropriate to include consumers at specific leading retailers in Pietermaritzburg, South Africa, namely, Pick n' Pay, Spar, Checkers and Woolworths. Although convenience sampling is the least reliable design, it was useful considering the researcher's time and resource constraints and, the exploratory nature of this study.

\subsection{Sample size}

The population statistics for Pietermaritzburg was accessed from the Msunduzi (2008) website which revealed that the approximate population in the Pietermaritzburg area is 600 000. A sample calculator was then used to calculate the sample size of the population via the internet (Raosoft, 2004), with a confidence level set at $95 \%$ and margin for error at $5 \%$. In order to achieve the largest sample size, the response of distribution was set at $50 \%$, which resulted in a sample size of 384 . However due to time and financial constraints, the survey was terminated after 313 respondents participated in the study.

\subsection{Data Analysis}

The data was prepared, captured and analysed using the SPSS statistical programme.

\subsection{Validity and Reliability}

Considering that validity is the extent to which the research findings accurately represent the situation under investigation (Wellman et al., 2005:142), and although there are different types of validity, due to the exploratory nature of this research, a pre-test of the questionnaire was conducted among 10 consumers to ascertain face validity.

Reliability assesses or measures the credibility and accuracy of a research study (Cooper and Schindler, 2006:352). The internal consistency of the questionnaire was calculated using Cronbach's Alpha since this test is an effective tool for checking the reliability of scales (Santos, 1999: para2). The Cronbach's alpha co-efficient was 0.677 which is a close to 0.7 , the acceptable reliability coefficient (Reynaldo and Santos, 1999). 


\section{Findings}

The vast majority of the respondents (93.9\%) were aware that South Africa is recovering from a recession, and $74.3 \%$ of the respondents indicated that they were affected by the economic recession. The majority of the respondents $(69.8 \%)$ also agreed to changing their shopping habits during the recession, to suit their budgets. With regard to brands, the vast majority (98.450 of respondents indicated that they were aware of private label brands and manufacturer brands.

In terms of the demographics, $45.7 \%$ of the respondents were Indian, followed by Blacks (34.7\%) which more or less mirrors the demographics of the KwaZulu-Natal Province. Table 2 reflects the average household income of the respondents.

Table 2. Household Income of Respondents

\begin{tabular}{|l|l|l|l|l|l|}
\hline \multicolumn{2}{|l}{} & Frequency & Percent & Valid Percent & $\begin{array}{l}\text { Cumulative } \\
\text { Percent }\end{array}$ \\
\hline \multirow{4}{*}{ Valid } & Missing Value & 11 & 3.5 & 3.5 & 3.5 \\
\cline { 2 - 6 } & R0-R1500 & 47 & 15.1 & 15.1 & 18.6 \\
\cline { 2 - 6 } & R1501-R1800 & 12 & 3.9 & 3.9 & 22.5 \\
\cline { 2 - 6 } & R1801-R2100 & 13 & 4.2 & 4.2 & 26.7 \\
\cline { 2 - 6 } & R2101-R2900 & 10 & 3.2 & 3.2 & 29.9 \\
\cline { 2 - 6 } & R2901-R6000 & 40 & 12.9 & 12.9 & 42.8 \\
\cline { 2 - 6 } & R6001-R10000 & 44 & 14.1 & 14.1 & 56.9 \\
\cline { 2 - 6 } & R10001-R14000 & 52 & 16.7 & 16.7 & 100.0 \\
\cline { 2 - 6 } & R14001-R18000 & 30 & 9.6 & 9.6 & \\
\cline { 2 - 6 } & R18000+ & 52 & 16.7 & 16.7 & 100.0 \\
\cline { 2 - 6 } & Total & 311 & 100.0 & & \\
\hline
\end{tabular}

The various hypotheses (Table 2) were assessed using the survey data, which was subjected to chi-square tests. Coakes and Steed (2003:195) state that there are two main types of chi-square tests, namely, the chi-square test for the goodness of fit which applies to the analysis of a single categorical variable, and the chi-square test for independence or relatedness which applies to the analysis of the relationships between two categorical variables. In this study, the chi-square test for the independence or relatedness was used. The data from Table 2 was used to construct the following LSM groups according to the SAARF ( no author, 2011).

Table 3. LSM Groups

\begin{tabular}{|l|l|l|l|}
\hline LSM Group & \multicolumn{4}{l|}{ Average Household Income } \\
\hline & Respondents & December 2009 & June 2010 \\
\hline LSM 1 & R0-R1500 & R1,386 & R1,496 \\
\hline LSM 2 & R1501-R1800 & R1,564 & R1,732 \\
\hline
\end{tabular}




\begin{tabular}{|l|l|l|l|}
\hline LSM 3 & R1801-2100 & R2,116 & R2,052 \\
\hline LSM 4 & R2101-2900 & R2,580 & R2,829 \\
\hline LSM 6 & R2901-R6000 & R3,627 & R3,832 \\
\cline { 2 - 4 } LSM 7 & R2901-R6000 & R5,990 & R6,398 \\
\hline LSM 8 & R6001-R10000 & R9, 694 & $\mathrm{R} 10,066$ \\
\hline LSM 9 & R10001-R14000 & R13,188 & R13,698 \\
\hline LSM 10 & R14001-R18000 & R17,809 & R18,414 \\
\hline
\end{tabular}

In Table 3, the columns 'December 2009' and 'June 2010' represent the average household income which classifies individuals into their respective LSM groups, which information was used to set up an estimated measure of each LSM group in order to distinguish between the 'High' and 'Low' LSM groups ( no author 2011). The "Low LSM" groups comprised LSM 1 to LSM 4, whereas the "High LSM" groups comprised LSM 8 to LSM 10.

Table 4. Chi-Square Tests- Hypothesis 1

\begin{tabular}{|l|l|l|l|}
\hline & Value & Df & Asymp. Sig. (2-sided) \\
\hline Pearson Chi-Square & .913 & 4 & .923 \\
\hline Likelihood Ratio & .920 & 4 & .922 \\
\hline Linear-by-Linear Association & .137 & 1 & .711 \\
\hline No of Valid Cases & 311 & & \\
\hline
\end{tabular}

With reference to hypothesis 1 , the results reflected in Table 4 indicate that at the 5\% significance level $\mathrm{H}_{0}$ can be accepted, since the p-values are greater than 0.05 . It is thus concluded that there is no relationship between the consumers' shopping habits and their brand preference during a recession.

Table 5. Chi-Square Tests- Hypothesis 2

\begin{tabular}{|l|l|l|l|}
\hline & Value & Df & Asymp. Sig. (2-sided) \\
\hline Pearson Chi-Square & 6.483 & 4 & .166 \\
\hline Likelihood Ratio & 6.636 & 4 & .156 \\
\hline Linear-by-Linear Association & .431 & 1 & .511 \\
\hline No of Valid Cases & 311 & & \\
\hline
\end{tabular}

The outcome of the chi-square test procedure with respect to Hypothesis 2 reflected in Table 5 reveals that at the $5 \%$ significance level $\mathrm{H}_{0}$ can be accepted, since the p-values are greater than 0.05 and, it can therefore be concluded that there is no relationship between the consumers' recession status and their brand choice. 
Table 6. Chi-Square Tests- Hypothesis 3

\begin{tabular}{|l|l|l|l|}
\hline & Value & Df & Asymp. Sig. (2-sided) \\
\hline Pearson Chi-Square & 39.928 & 20 & .005 \\
\hline Likelihood Ratio & 41.431 & 20 & .003 \\
\hline Linear-by-Linear Association & .215 & 1 & .643 \\
\hline No of Valid Cases & 311 & & \\
\hline
\end{tabular}

Table 6 reveals that with respect to hypothesis 3 , at the $5 \%$ significance level $\mathrm{H}_{0}$ is rejected, since the p-values are less than 0.05. It can therefore be concluded that there is a relationship between the respondents' change in shopping habits during the recession to suit their budget and, their preference for Manufacturer brands' compared to 'Private-label brands. Furthermore, the Spearman rank correlation coefficient of -.710 (p-value $=.000)$ indicated a significant strong negative relationship, implying that the respondents' change in shopping habits during the recession (to suit their budget), is, inversely related to their preference for Manufacturer brands' as compared to 'Private-label brands.

Table 7. Chi-Square Tests- Hypothesis 4

\begin{tabular}{|l|l|l|l|}
\hline & Value & Df & Asymp. Sig. (2-sided) \\
\hline Pearson Chi-Square & 57.207 & 20 & .000 \\
\hline Likelihood Ratio & 58.346 & 20 & .000 \\
\hline Linear-by-Linear Association & 6.997 & 1 & .008 \\
\hline N of Valid Cases & 311 & & \\
\hline
\end{tabular}

Table 7 reflects the results of the chi-square procedure to test hypothesis 4 . From Table 7 it can be deduced that at the $5 \%$ significance level, $\mathrm{H}_{0}$ is rejected since the p-values are less than 0.05 and, conclude that there is a relationship between the consumers' shopping habits during a recession (to suit their budgets) and, their inclination to buy Private label brands. The Spearman rank correlation coefficient was found to be $.141(\mathrm{p}$-value=.013) indicating a significant but weak positive relationship, implying that consumers' shopping habits during a recession is positively related to their budget and their inclination to buy Private label brands.

Table 8. Chi-Square Tests-Hypothesis 5

\begin{tabular}{|l|l|l|l|}
\hline & Value & Df & Asymp. Sig. (2-sided) \\
\hline Pearson Chi-Square & 31.645 & 12 & .002 \\
\hline Likelihood Ratio & 28.920 & 12 & .004 \\
\hline Linear-by-Linear Association & 5.289 & 1 & .021 \\
\hline N of Valid Cases & 311 & & \\
\hline
\end{tabular}

With respect to hypothesis 5, from the evidence in Table 8 it can at the 5\% significance level, be concluded that $\mathrm{H}_{0}$ is rejected since the p-values are less than 0.05 . It is thus concluded that there is a relationship between the respondents' brand loyalty and their preference for Manufacturer brands, irrespective of their financial status during recession. However in view 
of the Spearman rank correlation coefficient which was found to be -.132 ( $p$-value=.020) the relationship was a significant weak negative or inverse relationship, which meant that the respondents' brand loyalty is inversely related to their preference for Manufacturer brands, irrespective of their financial status during recession.

Table 9. Chi-Square Tests-Hypothesis 6

\begin{tabular}{|l|l|l|l|}
\hline & Value & Df & Asymp. Sig. (2-sided) \\
\hline Pearson Chi-Square & 9.449 & 3 & .024 \\
\hline Likelihood Ratio & 9.443 & 3 & .024 \\
\hline Linear-by-Linear Association & 2.577 & 1 & .108 \\
\hline N of Valid Cases & 311 & & \\
\hline
\end{tabular}

With reference to hypothesis 6 , as reflected in Table 9 , at the $5 \%$ significance level $\mathrm{H}_{0}$ is rejected, since the p-values are less than 0.05 . Thus, it can be concluded that during a recession, there is a relationship between respondents' brand loyalty, irrespective of whether or not they were affected by the recession. The relationship, although being significant was however according to the Spearman rank correlation coefficient .191 ( $\mathrm{p}$-value=.047), found to be a weak positive relationship, meaning that respondents' loyalty to brand is positively related to whether or not they were affected during the recession, that is, their recession status.

Table 10. Chi-Square Tests-Hypothesis 7

\begin{tabular}{|l|l|l|l|}
\hline & Value & Df & Asymp. Sig. (2-sided) \\
\hline Pearson Chi-Square & 12.908 & 3 & .005 \\
\hline Likelihood Ratio & 6.448 & 3 & .092 \\
\hline Linear-by-Linear Association & 609 & 1 & .435 \\
\hline N of Valid Cases & 311 & & \\
\hline
\end{tabular}

It is evident from Table 10 that at the $5 \%$ significance level $\mathrm{H}_{0}$ is rejected, since the $\mathrm{p}$-values are less than 0.05 and, it can be concluded that during the recession there is a relationship between brand loyalty and brand awareness of Private-Label and Manufacturer brands.

With respect to hypothesis 7, the Spearman rank correlation coefficient was found to be -.825 ( $p$-value $=.000$ ), indicating a significant and strong negative or inverse relationship, implying that respondents' brand loyalty is inversely related to their awareness of Private-Label and Manufacturer brands. 
Table 11. Chi-Square Tests-Hypothesis 8

\begin{tabular}{|l|l|l|l|}
\hline & Value & Df & Asymp. Sig. (2-sided) \\
\hline Pearson Chi-Square & 49.051 & 12 & .000 \\
\hline Likelihood Ratio & 51.346 & 12 & .000 \\
\hline Linear-by-Linear Association & 8.230 & 1 & .004 \\
\hline N of Valid Cases & 311 & & \\
\hline
\end{tabular}

According to Table 11, with respect to hypothesis 8 at the $5 \%$ significance level, $\mathrm{H}_{0}$ is rejected since the p-values are less than 0.05 . It is thus concluded that there is a relationship between brand loyalty during a recession and, the respondents' preference to buy Manufacturer brands instead of Private brands, irrespective of their financial status. Moreover, the Spearman rank correlation coefficient was found to be -.205 (p-value $=.000$ ) indicating a significant, yet weak negative or inverse relationship, which implies that the respondents' loyalty to a brand during the recession is inversely related with the respondents' preference to buy Manufacturer brands instead of Private brands, irrespective of their financial status.

Table 12. Relationship between LSM and Brand Loyalty

\begin{tabular}{|l|l|l|l|}
\hline & Value & Df & Asymp. Sig. (2-sided) \\
\hline Pearson Chi-Square & 11.680 & 9 & .232 \\
\hline Likelihood Ratio & 12.071 & 9 & .209 \\
\hline Linear-by-Linear Association & 6.509 & 1 & .011 \\
\hline N of Valid Cases & 311 & & \\
\hline
\end{tabular}

Finally, with respect to hypothesis 9 , the results reflected in Table 12 indicate that at the 5\% significance level $\mathrm{H}_{0}$ can be accepted, since the $\mathrm{p}$-values are greater than 0.05 , which implies that there is no relationship between the higher Living Standard Measure (LSM) groups loyal to established manufacturer brands and, their potential to switch to private label brands during an economic recession.

\section{Summary and Discussion of the Findings}

The exploratory survey has highlighted that with respect to hypotheses 1, 2 and 9, Ho is accepted, implying that there is no relationship among the variables hypothesised. However with respect to the rest of the hypotheses (3-8), relationships were found to exist, albeit strong positive or negative. In summary it was ascertained that a strong negative relationship exists between the respondents' change in shopping habits during the recession (to suit their budget) and, their preference for Manufacturer brands' compared to 'Private-label brands. The aforementioned finding is inconsistent with the literature and, implies that irrespective of the economic recession, the respondents have not migrated to a private brand. This could imply brand loyalty.

It was also ascertained that:

- A weak positive relationship exists between the consumers' shopping habits during a 
recession (to suit their budgets) and, their inclination to buy Private label brands.

- A weak negative relationship exists between the respondents' brand loyalty and their preference for Manufacturer brands, irrespective of their financial status during recession. This also supports Hypothesis 3 above - which implies that brand loyalty.

- A weak positive relationship exists between the respondents' brand loyalty and whether or not they were affected by the recession. This implies that a minority of the sample were not brand loyal, which again confirms that the majority are brand loyal.

- A strong negative relationship exists between the respondents' brand loyalty and awareness of Private-Label and Manufacturer brands.

- A weak negative relationship exists between the respondents' brand loyalty during a recession and, their preference to buy Manufacturer brands instead of Private brands, irrespective of their financial status.

The aforementioned findings are contrary to what the literature asserts. For example, TNS Research Surveys reported from a study amongst a sample of 2000 adults from the seven major metropolitan areas of South Africa, that the key decisions shoppers make if they are affected by the recession include, inter-alia, looking for cheaper brands (Neil, 2009: 1-9). Furthermore, in comparison to developed markets, consumers in developing markets such as South Africa, are less aware of private label brands and assume from the packaging and price that the brand is of inferior quality and, specifically aimed for people that cannot afford to purchase better quality manufacturer brands (AC Nielsen 2005). This may be a possible reason why they are reluctant to switch brands.

From another study conducted among consumers to determine their recessionary shopping behaviour by the Home Testers Club (no author 2010), it was ascertained that $91 \%$ of consumers agreed that they change their shopping habits to make ends meet, and $88.44 \%$ of these agreed to 'hold' these “thrifty, new" recessionary shopping habits, and $80.57 \%$ indicated that they bought cheaper lines and, $61.70 \%$ will stick to these lines even after the recession.

In South Africa, regardless of the growth of retail sales in key supermarket chains such as Shoprite, Pick n' Pay, Spar and Woolworths, private label brands have not achieved the level of penetration relative to other countries globally. For example, private label brands contribute $40 \%$ plus to the retail market in developed countries such as Switzerland and the UK while, there is only a $10.5 \%$ contribution to the retail market in South Africa (Durham, 2011:35). According to Beneke (2010: 205), a major concern in the South African retail market is the perception of consumers regarding private labels, and Beneke (2010) argues that even though it is considered normal for lower income groups to purchase private label brands for affordability reasons, issues such as trust and the availability of private labels result in consumers with limited financial resources purchasing manufacturer brands to avoid any perceived risk. Alternatively, higher Living Standards Measures (LSM 6-10) are wealthier and therefore are open to trial of private labels (Mawers 2006, cited by Beneke, 
2010: 205).

According to the AC Nielsen Report (2010), the growth of private label brands and the strength of the economy share an inverse relationship. The economic recession accounted for many consumers purchasing an increased amount of private label brands and, once they tried these brands, they realised that the quality of the brands did exceed their expectations (Nielsen, 2010: para12). Lamey et al. (2007, cited by Beneke, 2009:208) confirmed that the adoption rate of private labels is much faster during the economic recession compared to post recessionary adoption. Durham (2011: 35) supports this notion by declaring that there is no doubt that South African consumers have been encouraged to try private labels during 'trading down' buyer behavior within the recession period but other attributes such as packaging, quality and value for money has also accounted for the loyalty towards in store private labels.

According to The Solution Workshop report, the recession experienced in recent years has made South African consumers adapt and change their behaviour in order to cope financially during the recession. Furthermore, consumers were "tightening their belts" and controlling purchases by planning and budgeting, cutting back on any impulse spending and focusing on discounts, promotions and specials.

Although complete loyalty to a brand is very rare and, often amounted to a minimal percentage of irregular brand and category buyers (Hale, 2009:7), it seems evident from this exploratory study that very little brand switching takes place during an economic recession.

\section{Limitations of the Study and Future Research}

The study was only carried out among shoppers at selected stores in the Pietermaritzburg area of one province in South Africa, which presents a geographical limitation. Thus the findings should be interpreted with caution and not regarded as highly generalizable.

Since the general public was surveyed, some respondents asked for explanation of terms due to their limited level of understanding or proficiency in English. This therefore may have limited their response to unstructured questions.

Future researchers could consider conducting a national study among a large sample and compare the results with the exploratory study conducted in one, albeit large province in South Africa.

\section{References}

AC Nielsen. (2005). The Power of Private Label Growth [Online] Available: http://it.nielson.com/trends/documents/2003 privatelabel.pdf (25 June 2011)

AC Nielsen. (2010). The Global Staying Power of Private Label [Online] Available: http://blog.nielsen.com/nielsenwire/consumer/the-global-staying-power-of-private-label/ (25 June 2011) 
AC Nielsen. (2011). Nielsen Global Private Label Report. [Online] Available: http://blog.nielsen.com/nielsenwire/consumer/the-global-staying-power-of-private-label/ (25 June 2011)

Bass, A., \& Binder, S. (2005). Retail Space Invaders: Private Label Forces FMCG to Develop Brand Licensing Strategies AOnline] Available: http://www.brandchannel.com/papers_review.asp?sp_id=775 (29 May 2011).

Beneke, J. (2010). Consumer perceptions of private label brands within the retail grocery sector of South Africa. African Journal of Business Management, 4(2), 203-220.

Brown, T. J., Churchill, G. A., \& Tracy, J. B. (2009). Basic Marketing Research. (7th ed.). United States: Pearson Education.

Coakes S \& Steed L (2003) SPSS Analysis without Anguish, Version 11.0 for Windows, Milton: Miley Press: $135-145$.

Cooper, D. R., \& Schindler, P. S. (2007). Marketing Research. USA: McGraw Hill.

Das, S. (2009). PERCEPTOR® Plus: A Comprehensive, Predictive Approach for Building Strong Brands. [Online]. Available: http://www.ipsos.ru/services/pdf/Brand_Perceptor2.pdf (8 July 2011).

Durham, L. (2011). Opportunities and Challenges for South African Retailers [Online] Available:

http://www.supermarket.co.za/SR_Downloads/S\&R\%20May\%202011\%20Trend\%20tracker. pdf (28 August 2011).

Feldstein, M. (2003). Business Cycle Dating Committee, National Bureau of Economic Research. [Online] Available: http://www.nber.org/cycles/recessions.pdf [Accessed 17 May 2011].

Hague, P. (1993). Questionnaire Design. England: Clays LTD.

Hale, T. (2009) Shopper and Consumer Insight, The Nielsen Company [Online]. Available: http://blog.nielsen.com/nielsenwire/consumer/think-all-store-brand-buyers-are-the-same-thin k-again/ [Accessed: 2011, 10 June]

Hata, P. (2008) What Are The Causes of Economic Recession? [Online] Available: http://www.freearticles.co.za/culture-and-society/current-affairs/what-are-causes-economic-re cession.html [Accessed 2011, 9 March]

Haupt, P. (2006). The SAARF Universal Living Standards Measure [Online] Available: http://www.saarf.co.za/LSM/lsm-article.htm (25 May 2011).

Keller, K. L. (2008). Strategic Brand Management. (3rd ed.). New Jersey: Prentice Hall.

Kotler, P., \& Armstrong, G. (1996). Principles of Marketing. (7th ed.). New Jersey: Prentice Hall. 
Kotler, P., \& Keller, K. L. (2006). Marketing Management. (12th ed.). New Jersey: Prentice Hall.

Kumar, N., \& Steenkamp, J. (2007). Private label strategy: How to meet the Store Brand Challenge. Boston: Harvard Business School Press.

Leahy, T. (1987). Branding: The Retailer's point of view. In: J.M. Murphy (eds) Branding: A Key Marketing Tool. London: The Macmillan Press Ltd, 116-124.

Msunduzi. (2009). Pietermaritzburg Msunduzi: Home [Online]. Available: http://www.msunduzi.gov.za/site/home (10 March 2011).

Murphy, M. J. (1987). Branding: A Key Marketing Tool. London: Macmillan Press.

Neil, H. (2009) Is There A New Consumer Mindset? [Online] Available: http://www.theannual.co.za/site/annual/usr/home/theani/public_html/the-research/is-there-a-n ew-consumer-mindset/ [Accessed: 2011, 16 July]

No author. (2010). Post Recession Shopping Habits Survey [Online] Available: http://www.hometesterclub.com/rsa/PostRecession.asp (15 March 2011).

No author. (2010). South African Spending Patterns Altered [Online] Available: http://satrader.com/2010/11/26/south-african-spending-patterns-altered/ (5 March 2011)

No author. (2011). About LSM. [Online] Available: http://econ.worldbank.org/ PK:3358997,00.html (25 May 2011)

Raosoft. (2004). Sample Size Calculator [Online] Available: http://www.raosoft.com/samplesize.html (17 March 2011)

Reynaldo, J., \& Santos, A. (1999) Cronbach's Alpha: A Tool for Assessing the Reliability of Scales [Online] Available: http://www.joe.org/joe/1999april/tt3.php [Accessed: 2011, 14 June].

Silverstein, B. (2008). Brand Progression in a Recession. [Online] Available: http://www.brandchannel.com/features_effect.asp?pf_id=414 (11 June 2011)

Simpson. (n.d.). South Africans believe recession is far from over [Online]. Available: http://www.bizcommunity.com/PressOffice/PressRelease.aspx ?i=114337\&ai=43576 March 2011)

Wellman, C., Kruger, F., \& Mitchell, B. (2005). Research Methodology. Cape Town: Oxford University Press. 